\title{
Biomass production of yeast isolate from salad oil manufacturing wastewater
}

\author{
Shaokui Zheng ${ }^{\mathrm{a}, \mathrm{b}, *}$, Min Yang ${ }^{\mathrm{b}}$, Zhifeng Yang ${ }^{\mathrm{a}}$ \\ a School of Environment, Institute of Environmental Sciences, Beijing Normal University, Beijing 100875, China \\ ${ }^{\mathrm{b}}$ Research Center for Eco-Environmental Sciences, Chinese Academy of Sciences, Beijing 100085, China
}

Received 10 January 2004; received in revised form 20 September 2004; accepted 23 September 2004

Available online 21 November 2004

\begin{abstract}
Conversion of oil-rich salad oil manufacturing wastewater (SOMW) into protein source for animal feed through biomass production of yeast isolate was investigated in this study. Five species of yeasts, including Rhodotorula rubra, Candida tropicalis, $C$. utilis, C. boidinii, Trichosporon cutaneum, were isolated from SOMW following enrichment culture. Of them, C. utilis was chosen as the sole biomass producer in the study due to its greatest oil uptake rate, $0.96 \mathrm{~kg} \mathrm{oil} \mathrm{kg}^{-1} \mathrm{biomass} \mathrm{d}^{-1}$, and highest specific growth rate, $0.25 \mathrm{~h}^{-1}$. The cells of $C$. utilis contained $26 \%$ protein, $9 \%$ crude lipid, $55 \%$ carbohydrate and balanced amino acid compositions. The initial N:C ratio in SOMW drastically influenced oil reduction efficiency, biomass production and protein content of $C$. utilis, and therefore a range between 1:6 and 1:8 was recommended in consideration of these three factors simultaneously.
\end{abstract}

(C) 2004 Elsevier Ltd. All rights reserved.

Keywords: Oil-rich wastewater; Microbial biomass; Protein; Yeast; Candida utilis

\section{Introduction}

Since World War II, some high quality yeast species such as Candida and Saccharomyces spp. has been employed as a producer of microbial protein to convert agro-industrial wastes, e.g., effluents from paper mill and olive mill, into a valuable protein supplement for animal feeds (Ejiofor et al., 1996; Gharsallah, 1993; Nigam, 1998). The process is generally thought to be an attractive way to both enhance wastewater purification and increase resource utilization.

Recently, more and more yeast species are isolated from nature and proven superior to conventional protein producer in laboratory or field studies (Nigam, 2000; Arnold et al., 2000; Urano et al., 2002; Yang et al., 2003), which offers more choices for the microbial

\footnotetext{
${ }^{*}$ Corresponding author. Tel.: +86 105880 9266/6220 9266; fax: +86 $1058800397 / 62200397$.

E-mail address: zshaokui@yahoo.com.cn (S. Zheng).
}

protein process. For example, a yeast species, $C$. langeronii, is isolated under selective conditions as an alternative microorganism of $C$. utilis because of the inability of the latter to utilize L-arabinose at temperatures above $42{ }^{\circ} \mathrm{C}$ in the absence of vitamins (Nigam, 2000). In comparison with a strain of $C$. utilis, the isolate, Galactomyces geotrichum T2B, gives consistently higher biomass yields from silage effluent along with excellent nutrient removal (Arnold et al., 2000). The co-culture of two yeast isolates, C. halophila and Rhotorula glutinis, could effectively remove organic pollutants, above $85 \%$, from fermentative wastewater even when ammonium-nitrogen concentration reaches as high as about $19 \mathrm{gl}^{-1}$ (Yang et al., 2003).

In salad oil manufacturing, a considerable amount of fatty acid in raw vegetable oil is separated from glyceride by a water washing process in the refining plant, and discarded as high-strength salad oil manufacturing wastewater (SOMW) (Zheng et al., 2001). The effluent contains no harmful substance and is a potential source 
of cell mass production. This study sought to determine if it is possible to achieve effective resource reutilization from SOMW as well as high organic utilization efficiency through the use of yeast isolate. In the study, we evaluated the biomass production from SOMW using yeast isolate following enrichment, isolation and identification. Aiming to improve oil reduction, protein content and cell yield, the study thereafter discussed the effect of initial $\mathrm{N}: \mathrm{C}$ ratio.

\section{Methods}

\subsection{Enrichment, isolation and identification of yeast}

Field soil was collected from several spots contaminated with SOMW and enriched in $500 \mathrm{ml}$ Erlenmeyer flasks containing $150 \mathrm{ml}$ of 10 -fold diluted SOMW at $170 \mathrm{rpm}$ on a reciprocal shaker at $25^{\circ} \mathrm{C}$. The $\mathrm{pH}$ of the solution was adjusted to $5.5 \%$, and $0.25 \%$ sodium propionate was added to the solution, which minimized the propagation of bacteria and molds. The cultivation was conducted in a fill-and-draw mode for 20 days during which the solution was changed once a day. After being cultured in YPD medium $(2 \%$ dextrose, $1 \%$ yeast extract, $1 \%$ casein peptone) for 2 days, the culture was transferred to YPD agar plates for isolation. The isolated yeast strains were identified based on morphological and biochemical characteristics described by Kreger-van Rij (1984).

\subsection{Comparison of yeast species}

The yeast isolates were individually inoculated into YPD medium and cultured for $48 \mathrm{~h}$ at $25^{\circ} \mathrm{C}$ on a rotary shaker at $170 \mathrm{rpm}$ under the aseptic conditions. The cells were centrifuged at $4000 \mathrm{rpm}$ for $15 \mathrm{~min}$ and washed three times using physiological saline prior to storage in aseptic physiological saline at $4{ }^{\circ} \mathrm{C}$. Subsequently, a loopful of the yeast cells was individually inoculated and cultured at $\mathrm{pH} 5.5$ in 51 of 10 -fold diluted SOMW to which about $3 \mathrm{~g} \mathrm{NH}_{4} \mathrm{Cl}$ was added to give an initial $\mathrm{N}: \mathrm{C}$ ratio of about 1:25. The liquids were aerated at $25^{\circ} \mathrm{C}$ by air pump to maintain a dissolved oxygen level of $2 \mathrm{mg}^{-1}$. Cell growth was monitored by dry weight of yeast biomass in $10 \mathrm{ml}$ culture following centrifugation at $4000 \mathrm{rpm}$ for $15 \mathrm{~min}$. Finally, specific growth rate and oil reduction efficiency of individual yeast species were summarized over the experimental period.

\subsection{Yeast cell composition analyses and effect of initial $N$ : C ratio}

C. utilis OZ993 cells, which was cultured in 51 of 10fold diluted SOMW with an initial $\mathrm{N}: \mathrm{C}$ of $1: 25$, were collected to analyze its chemical composition and to use as consequent experimental inocula. The analytical items of chemical composition included crude protein, crude lipid, amino acid, and so on.

To investigate the effect of initial $\mathrm{N}: \mathrm{C}$ on $C$. utilis OZ993, a series of experiments was conducted in 51 of 10-fold diluted SOMW with $\mathrm{N}: \mathrm{C}$ ratios ranging between $1: 3$ and 0 . In the beginning, the inocula of $C$. utilis OZ993 were inoculated to achieve an initial cell concentration of approximately $1 \mathrm{gl}^{-1}$. Cell mass, protein content and oil reduction were respectively measured at the end of experimental period of $24 \mathrm{~h}$.

\subsection{Analytical methods}

Analyses of the wastewater followed standard methods (CSEPA, 1998). Prior to chemical composition analysis of yeast cells as described by Xia and Zhu (1994), the resulting cells were harvested by centrifugation and desiccated at $103-105^{\circ} \mathrm{C}$ for $6 \mathrm{~h}$. Among them, crude protein was estimated by the method of Kjeldahl and crude lipid by the Soxhelt ether extraction method. The ash content was determined after combusting samples at $550-560^{\circ} \mathrm{C}$ for $2 \mathrm{~h}$. Amino acids were analyzed with a Hitachi Amino Acid Auto-Analyzer (model 825-10) after hydrolyzing the yeast cells in $6 \mathrm{~N} \mathrm{HCl}$ for $22 \mathrm{~h}$ at $110^{\circ} \mathrm{C}$ under vacuum.

\section{Results and discussion}

Table 1 listed the characteristics of SOMW sample. It contained a high amount of oil, typically $90 \mathrm{gl}^{-1}$, which consisted mainly of fatty acids. There was also plentiful phosphorus content in the SOMW that amounted to $6.5 \mathrm{gl}^{-1}$. In contrast, the total nitrogen concentration was extremely low, at $154 \mathrm{mg}^{-1}$, which led to $\mathrm{N}: \mathrm{C}$ ratios as low as 1:265.

A total of ten isolates capable of utilizing SOMW were obtained from an enriched culture of SOMW. According to their morphological and physiological characteristics, the isolates consisted of five species belonging to three genera and labeled as OZ991OZ995 in Table 2. Candida spp., including C. tropicalis

Table 1

Characteristics of salad oil manufacturing wastewater used in the study

\begin{tabular}{lc}
\hline Component & Concentration \\
\hline Chemical oxygen demand $\left(\mathrm{gl}^{-1}\right)$ & $134 \pm 0.38$ \\
Total organic carbon $\left(\mathrm{gl}^{-1}\right)$ & $39 \pm 0.45$ \\
Oil $\left(\mathrm{gl}^{-1}\right)$ & $90 \pm 1.12$ \\
Carbohydrate $\left(\mathrm{gl}^{-1}\right)$ & $9.1 \pm 0.41$ \\
Protein $\left(\mathrm{gl}^{-1}\right)$ & $0.44 \pm 0.01$ \\
Total nitrogen $\left(\mathrm{gl}^{-1}\right)$ & $0.15 \pm 0.01$ \\
Total phosphorus $\left(\mathrm{gl}^{-1}\right)$ & $6.5 \pm 0.15$ \\
$\mathrm{pH}$ & $8.5-9.0$ \\
\hline
\end{tabular}

Values are the means \pm standard errors of three determinations. 
Table 2

Characteristics of yeast species isolated from soil at the sites contaminated with SOMW

\begin{tabular}{|c|c|c|c|c|c|}
\hline Strain number & OZ991 & OZ992 & OZ993 & OZ994 & OZ995 \\
\hline $\begin{array}{l}\text { Morphological characteristics } \\
\text { Shape of vegetative cell } \\
\text { (Pseudo)mycelium formation }\end{array}$ & $\begin{array}{l}\text { Oval } \\
-\end{array}$ & $\begin{array}{l}\text { Oval } \\
+\end{array}$ & $\begin{array}{l}\text { Oval } \\
+\end{array}$ & $\begin{array}{l}\text { Oval } \\
+\end{array}$ & $\begin{array}{l}\text { Cylindrical } \\
+\end{array}$ \\
\hline $\begin{array}{l}\text { Assimilation characteristics } \\
\text { Trehalose } \\
\text { Lactose } \\
\text { Raffinose } \\
\text { Soluble starch } \\
\text { D-Xylose } \\
\text { Succinic acid } \\
\text { Citric acid } \\
\text { Nitrate }\end{array}$ & $\begin{array}{l}+ \\
- \\
+ \\
- \\
+ \\
+ \\
- \\
-\end{array}$ & $\begin{array}{l}+ \\
- \\
- \\
+ \\
+ \\
+ \\
+ \\
-\end{array}$ & $\begin{array}{l}+ \\
- \\
+ \\
- \\
- \\
- \\
- \\
+\end{array}$ & $\begin{array}{l}- \\
- \\
- \\
- \\
+ \\
+ \\
- \\
+\end{array}$ & $\begin{array}{l}+ \\
+ \\
- \\
- \\
+ \\
+ \\
- \\
-\end{array}$ \\
\hline Yeast species & R. rubra & C. tropicalis & C. utilis & C. boidinii & Trichosporon cutaneum \\
\hline
\end{tabular}

Codes for responses to tests: $(+)$ positive; $(-)$ negative.

OZ992, C. utilis OZ993, C. boidinii OZ994, were prevalent. All of yeast species could form pseudomycelium except Rhodotorula rubra OZ991. Only C. utilis OZ993 and $C$. boidinii OZ994 could assimilate nitrate.

Of the five yeast species, C. utilis OZ993 had great advantages over other isolates because it had both the greatest oil uptake rate, $0.96 \mathrm{~kg}_{\text {oil }} \mathrm{kg}^{-1}$ biomass $\mathrm{d}^{-1}$, and the highest specific growth rate, $0.25 \mathrm{~h}^{-1}$, approximately double those of the other strains except $C$. boidinii (Table 3). C. utilis is frequently used for the production of microbial biomass from food processing waste because of its ability to utilize a variety of carbon sources rapidly (Nigam, 1998; Choi and Park, 2003; Prior et al., 1981), which was also demonstrated in the study. However, the specific growth rate of $C$. utilis OZ993 in the study was roughly half that of $C$. utilis Y900 grown in pineapple cannery effluent reported by Nigam (1998), which was suspected to result from nitrogen deficiency in SOMW. In addition, C. boidinii OZ994 had the second fastest oil uptake rate, $0.94 \mathrm{~kg}_{\text {oil kg }} \mathrm{kg}^{-1}$ biomass $\mathrm{d}^{-1}$ while $R$. rubra OZ991 was growing the second fastest, $0.24 \mathrm{~h}^{-1}$. In consideration of pollutant removal and biomass recovery together, C. utilis OZ993 was chosen as the biomass producer and evaluated in the following study.
The chemical composition of C. utilis OZ993 cells generated in 10-fold diluted SOMW, including lipid, protein and essential amino acid, was analyzed in Tables 4 and 5. The crude protein content of C. utilis OZ993 cells was only $26 \%$, roughly half those values, $55.3 \%$ and 43\% respectively, reported by Nigam (1998) and Choi and Park (2003) for C. utilis grown in agro-industrial wastes. In contrast, the cells of $C$. utilis OZ993 contained up to $55 \%$ total carbohydrate that was far higher than the value, $27.4 \%$, reported on C. utilis Y900 cultured in pineapple cannery effluent (Nigam, 1998). It was possibly due to fatty acids in SOMW being preferentially converted into carbohydrate rather than protein in C. utilis OZ993 cells, due to nitrogen deficiency in SOMW. There was about $85 \%$ BOD reduction over the cultivation period. In addition, the yeast cells contained a high concentration of crude lipid, 9\%, as a result of its origin from oil-rich SOMW. The yeast protein could be useful in combination with other low-lipid feedstuffs such as green fodder.

As shown in Table 5, the microbial protein produced by SOMW-based $C$. utilis OZ993 contained all the essential amino acids for animal feed. The amino acid composition was well balanced and compares well with that produced by C. utilis Y900 (Nigam, 1998) and

Table 3

The oil uptake rate (OUR), and maximal specific growth rates $\left(\mu_{\max }\right)$ of five yeast species in 10 -diluted SOMW at $25^{\circ} \mathrm{C}$

\begin{tabular}{llllll}
\hline Species & OZ991 & OZ992 & OZ993 & OZ994 & OZ995 \\
\hline OUR $\left(\mathrm{kg} \mathrm{oil} \mathrm{kg}^{-1}\right.$ biomass d & \\
$\mu_{\max }\left(\mathrm{h}^{-1}\right)$ & 0.64 & 0.71 & 0.96 & 0.94 & 0.62 \\
\hline
\end{tabular}

Table 4

Composition analyses of C. utilis OZ993 from SOMW

\begin{tabular}{lllll}
\hline Composition & Crude protein & Crude lipid & Ash & Carbohydrate \\
\hline Content (\% dry weight) & $26.0 \pm 0.2$ & $9.0 \pm 0.6$ & $8.0 \pm 0.3$ & $55.0 \pm 0.9$ \\
\hline A
\end{tabular}

Ammonium chloride, about $3 \mathrm{gl}^{-1}$, was added to 10 -fold diluted SOMW. Values are the means \pm standard errors of three determinations. 
Table 5

Amino acid composition of proteins from the different sources

\begin{tabular}{|c|c|c|c|c|}
\hline \multirow[t]{2}{*}{ Amino acid } & \multicolumn{4}{|c|}{ Protein source (as \% of total protein) } \\
\hline & $\begin{array}{l}\text { C. utilis } \\
{\text { OZ } 993^{\mathrm{a}}}^{\text {a }}\end{array}$ & $\begin{array}{l}\text { C. utilis } \\
\text { Y } 900^{\mathrm{b}}\end{array}$ & Soybean $^{\mathrm{c}}$ & $\begin{array}{l}\text { FAO } \\
\text { guideline }^{d}\end{array}$ \\
\hline Lysine & 7.8 & 7.7 & 6.6 & 4.2 \\
\hline Threonine & 4.7 & 4.6 & 4.3 & 2.8 \\
\hline Valine & 4.0 & 4.7 & 5.0 & 4.2 \\
\hline Methionine & 1.0 & 1.0 & 1.3 & 2.2 \\
\hline Isoleucine & 4.1 & 4.0 & 4.9 & 4.2 \\
\hline Leucine & 7.9 & 6.2 & 8.0 & 4.8 \\
\hline Phenylalanine & 3.4 & 3.4 & - & 2.8 \\
\hline Histidine & 1.5 & 1.6 & - & \\
\hline Arginine & 4.4 & 6.4 & - & \\
\hline
\end{tabular}

soybean (Lo and Moreau, 1986). Most of the essential amino acid content (as \% of total protein) equalled or surpassed the Food Agricultural Organization (FAO) guideline (1980). Its high lysine and threonine content suggested that the yeast protein would be suitable as the protein supplement to increase the protein quality of cereal-based cattle feed.

The effect of the initial $\mathrm{N}: \mathrm{C}$ ratio on oil reduction, biomass production and protein content of $C$. utilis OZ993 cells was shown in Fig. 1. The initial N:C ratio seemed to play a very important role in the variation of these three parameters. In Fig. 1, the initial N:C ratio of 1:5 seemed optimal for the proliferation of C. utilis OZ993, at which a maximum cell mass, about $3.2 \mathrm{gl}^{-1}$, was obtained. In the meanwhile, the oil reduction efficiency gradually decreased when initial $\mathrm{N}: \mathrm{C}$ ratio increased, and nearly remained consistent, $83-85 \%$,

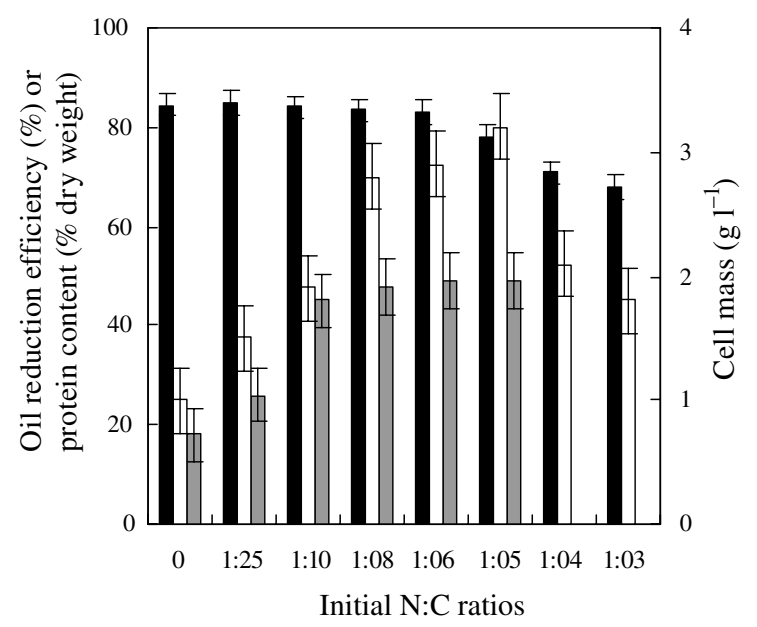

Oil Reduction Efficiency $\square$ Protein Content $\square$ Cell Mass

Fig. 1. Effect of initial $\mathrm{N}: \mathrm{C}$ ratio on the oil reduction, protein content and cell mass production at $25^{\circ} \mathrm{C}$. when the initial $\mathrm{N}: \mathrm{C}$ ratio ranged between 0 and 1:6. This implied that less nitrogen addition promoted the oil reduction by $C$. utilis OZ993, and that the highest oil reduction efficiency would be achieved when without nitrogen supplement. However, Nigam (1998) observed that $C$. utilis Y900 grown in oligotrophic pineapple cannery effluent achieved a better COD reduction following the supplementation of nutrient source. The difference between them might be owed to the origin of yeast strain. In our study, the yeast strains were isolated from oligotrophic SOMW rather than transferred from a eutrophic slant culture so they had a better adoptability for the oligotrophic surroundings. The result indicated that even same species might perform differently because of their material origins.

On the other hand, lower $\mathrm{N}: \mathrm{C}$ ratios adversely affected the cellular protein content of C. utilis OZ993. There was substantial reduction in protein level of cells, from $49 \%$ to $18 \%$, when the $\mathrm{N}$ :C ratios gradually declined from 1:5 to 0 . At the same time, the protein content, $48-49 \%$, was almost invariable at the $\mathrm{N}: \mathrm{C}$ ratios ranging between 1:8 and 1:5. At its summit, the protein content of C. utilis OZ993 cells was comparable to that reported in other literatures (Nigam, 1998; Choi and Park, 2003), indicating that an appropriate amount of nitrogen source will be of the key to harvest high-quality yeast protein in the study.

From the results mentioned above, it seemed to imply that one objective must be at a cost of others. In this study, a range of initial $\mathrm{N}: \mathrm{C}$ ratio between 1:6 and 1:8 would be preferentially recommended since three parameters equalled or approximated to their individual maximum values under the conditions.

The presented study demonstrated that SOMW could be readily converted by yeast isolate into yeast protein, as well as improving organic removal efficiency when the appropriate amount and proper type of inorganic nitrogen source was added.

\section{Acknowledgements}

The research is financially supported by the committee of National Science Foundation of China (NSFC) (No. 50078053) and the Scientific Research Foundation for the Returned Overseas Chinese Scholars, State Education Ministry.

\section{References}

Arnold, J.L., Knapp, J.S., Johnson, C., 2000. The use of yeast to reduce the polluting potential of silage effluent. Water Res. 34, 3699-3708.

Choi, M.H., Park, Y.H., 2003. Production of yeast biomass using waste Chinese cabbage. Biomass Bioenergy 25, 221-226. 
Committee of State Environmental Protection Agency (CSEPA), 1998. Water and Wastewater Monitoring and Analysis, third edition. China Construction Industry Press, Beijing.

Ejiofor, A.O., Chisti, Y., MooYoung, M., 1996. Culture of Saccharomyces cerevisiae on hydrolyzed waste cassava starch for production of baking-quality yeast. Enzyme Microb. Technol. 18, 519525.

Food and Agriculture Organization of the United Nations, 1980. Amino acid content of foods and biological data on proteins. FAO Nutritional Studies No. 24, Rome, Italy.

Gharsallah, N., 1993. Production of single cell protein from olive mill wastewater by yeasts. Environ. Technol. 14, 391-395.

Kreger-van Rij, N.J.W., 1984. The Yeasts: a Taxonomic Study, third ed. Elsevier Science Publishers, Amsterdam.

Lo, S.N., Moreau, J.R., 1986. Mixed culture microbial protein from waste sulphite pulping II. Its production on pilot scale and use in animal feed. Can. J. Chem. Eng. 64, 639-646.

Nigam, J.N., 1998. Single cell protein from pineapple cannery effluent. World J. Microbiol. Biotechnol. 14, 693-696.
Nigam, J.N., 2000. Cultivation of Candida langeronii in sugar cane bagasse hemicellulosic hydrolyzate for the production of single cell protein. World J. Microbiol. Biotechnol. 16, 367-372.

Prior, B.A., Botha, M., Custer, M., Casaleggio, C., 1981. Fermentation of pineapple cannery effluent by Candida utilis. In: MooYoung, M., Robinson, C.W. (Eds.), In Advances in Biotechnology, vol. 2. Pergamon Press, New York, pp. 337-342.

Urano, N., Sasaki, E., Ueno, R., Namba, H., Shida, Y., 2002. Bioremediation of fish canery wastewater with yeast isolated from a drainage canal. Mar. Biotechnol. 4, 559-564.

Xia, Y.Y., Zhu, D., 1994. Analysis Handbook on Feedstuff. China Chemistry Industry Press.

Yang, Q., Yang, M., Hei, L., Zheng, S., 2003. Using ammoniumtolerant yeast isolates: Candida halophila and Rhodotorula glutinis to treat high strength fermentative wastewater. Environ. Technol. 24 (3), 383-390.

Zheng, S., Yang, M., Lv, W., Fang, L., 2001. Study on sludge expansion during treatment of salad oil manufacturing wastewater by yeast. Environ. Technol. 22, 533-542. 